\title{
PENERAPAN MODEL PEMBELAJARAN KOOPERATIF TIPE THINK PAIR SQUARE (TPSq) UNTUK MENINGKATKAN HASIL BELAJAR SISWA KELAS VII SMPN 4 KOTA BENGKULU
}

\author{
Shelly Trihasari ${ }^{1}$, Saleh Haji ${ }^{2}$ \\ ${ }^{1,2}$ Program Pascasarjana Pendidikan Matematika FKIP, Universitas Bengkulu \\ Jalan WR Supratman Kandang Limun, Bengkulu, Indonesia \\ e-mail: ${ }^{1}$ shellytrihasari@gmail.com; ${ }^{2}$ salehhaji@unib.ac.id;
}

\begin{abstract}
Abstrak
Penelitian ini bertujuan untuk menyelidiki peningkatan hasil belajar siswa melalui penerapan model pembelajaran kooperatif tipe Think Pair Square (TPSq). Desain penelitian yang digunakan adalah Penelitian Tindakan Kelas dengan teknik pengumpulan data menggunakan lembar observasi kegiatan belajar siswa dan tes. Subjek penelitian adalah siswa kelas 1 SMPN 4 Kota Bengkulu tahun akademik 2018/2019 dengan jumlah siswa 32 orang yang terdiri dari 16 laki-laki dan 16 perempuan. Penelitian ini dilakukan dalam tiga siklus dari 7 September 2018 hingga 13 Oktober 2018. Hasil penelitian menunjukkan bahwa penerapan model pembelajaran kooperatif tipe Think Pair Square meningkatkan hasil belajar matematika. Kegiatan belajar siswa dapat ditingkatkan dengan pemberian lembar kerja siswa yang berisi proses penyelesaian sehingga memudahkan siswa dalam mengerjakan lembar kerja siswa, menghargai siswa dengan tepuk tangan setelah mereka menyampaikan pendapat mereka, dan membagi siswa dalam kelompok heterogen berdasarkan kemampuan akademik. Peningkatan hasil belajar siswa dapat dilihat dari peningkatan nilai rata-rata siswa dari siklus pertama ke siklus ketiga yaitu: 74,35; 79,91; 81,14 dan persentase ketuntasan belajar klasikal dari siklus I ke siklus III adalah: 76,67\%; 83,33\%; $93,33 \%$.
\end{abstract}

Kata Kunci: model pembelajaran kooperatif, prestasi belajar, think pair square

\section{PENERAPAN MODEL PEMBELAJARAN KOOPERATIF TIPE THINK PAIR SQUARE (TPSq) UNTUK MENINGKATKAN HASIL BELAJAR SISWA KELAS VII SMPN 4 KOTA BENGKULU}

\begin{abstract}
This research aimed to investigate the implementation of cooperative learning model in the type of Think Pair Square (TPSq) in order to improve students' achievement. The design of the research was a Classroom Action Research with the techniques of collecting the data were through the observation sheet of students' learning activities and summative test. The subject of the research were the 1st grade students of SMPN 4 Bengkulu City academic year of 2018/2019 with total amount of students were 32 consist of 16 males and 16 females students. The research was conducted in three cycles from 7th September 2018 until 13 October 2018. The result of the research showed that the implementation of cooperative learning model type Think Pair Square improved students' achievement in Mathematic. Students' learning activities were improved by giving the students work sheet that contains a completion process so that facilitate students in working on the students work sheet, appreciating the student with applause after they delivered their opinion, and dividing students in heterogenous groups based on their academic skills. The improvement on students' achievement can be seen from the increasing on the mean of students' scores from first cycle to third cycle namely: $74.35 ; 79.91 ; 81.14$ and the percentage of classical learning completeness from first cycle to third cycle is : $76.67 \% ; 83.33 \%$; $93.33 \%$.
\end{abstract}

Keywords: cooperative learning model, learning achievement, think pair square

\section{Pendahuluan}

Matematika merupakan salah satu mata pelajaran yang memiliki peranan penting dalam dunia pendidikan. Oleh karena itu, matematika diajarkan mulai dari pendidikan dasar, menengah, sampai perguruan tinggi. Selain itu, matematika menjadi dasar dari berbagai bidang ilmu seperti 
kimia, fisika, dan ekonomi. Dengan mempelajari matematika diharapkan siswa mampu untuk mengembangkan pola pikirnya dalam menyelesaikan permasalahan yang dihadapi. Sebagian orang beranggapan bahwa pelajaran matematika merupakan pelajaran yang sulit untuk dipahami. Pelajaran matematika juga dianggap membosankan dan membuat jenuh karena membahas rumus-rumus dalam penyelesaiannya sehingga membuat siswa malas dan kurang aktif dalam pembelajaran.

Berdasarkan observasi awal dan wawancara dengan guru matematika kelas VII 3 SMPN 4 Kota Bengkulu pada tanggal 3 Agustus 2018, selama proses pembelajaran berlangsung, diketahui bahwa (1) banyak siswa yang tidak memperhatikan guru dan sibuk mengobrol ketika guru menyampaikan materi pelajaran, (2) saat guru memberikan kesempatan kepada siswa untuk bertanya, tidak ada siswa yang merespon untuk bertanya, (3) tanggung jawab dan kerja sama siswa dalam kelompok masih rendah karena siswa cenderung mengandalkan teman untuk mengerjakan tugas kelompok yang diberikan, (4) hasil belajar siswa tergolong rendah, terlihat dari nilai rata-rata ulangan harian pada Materi Pokok Bilangan yaitu sebesar 43,31 yang masih dibawah kriteria ketuntasan minimal (KKM) yang ditetapkan sekolah yaitu 75 .

Pembelajaran matematika yang didominasi oleh guru akan membuat siswa merasa bosan dan menyebabkan siswa acuh terhadap materi pelajaran. Hal ini menyebabkan siswa kurang antusias terhadap materi pelajaran yang diberikan. Jika hal ini terus berlangsung, maka pembelajaran tidak akan efektif dikarenakan minimnya partisipasi siswa dalam kegiatan belajar mengajar sehingga akan berdampak terhadap hasil belajar siswa. Untuk itu, sangat penting bagi guru untuk mengatasi permasalahan tersebut dengan menerapkan cara yang tepat dalam kegiatan pembelajaran di kelas dengan melibatkan siswa untuk terlibat aktif dalam kegiatan pembelajaran.

Salah satu upaya yang dapat diterapkan guru untuk mengatasi permasalahan tersebut adalah dengan menerapkan model pembelajaran kooperatif. Melalui model pembelajaran kooperatif siswa dituntut untuk menyelesaikan permasalahan yang diberikan secara berkelompok. Dengan demikian diharapkan siswa mampu untuk saling bekerja sama dan bertukar pendapat dalam menyelesaikan permasalahan serta membuat siswa terlibat aktif dalam proses pembelajaran.

Salah satu tipe model pembelajaran kooperatif adalah Think Pair Square (TPSq).
TPSq cocok digunakan karena siswa dapat melewati tahap-tahap sebagai berikut: siswa berfikir (think), berpasangan (pair), berkelompok (square) (Utami dkk., 2014: 8).

Dengan demikian siswa akan termotivasi untuk belajar, saling bertukar pendapat, dan saling membantu dalam memahami materi pelajaran. Komunikasi antar siswa dalam kelompok akan lebih intensif dan memupuk rasa tanggung jawab siswa dalam belajar.

Model pembelajaran kooperatif tipe TPSq diharapkan mampu meningkatkan kerjasama siswa dalam kelompok dan mampu membantu siswa dalam menyelesaikan permasalahan secara bersama-sama. Dengan demikian, penerapan model pembelajaran kooperatif tipe TPSq diharapkan mampu meningkatkan pemahaman siswa dan membuat siswa terlibat aktif dalam proses pembelajaran sehingga berdampak terhadap meningkatnya hasil belaja matematika siswa. Berdasarkan uraian diatas, peneliti melakukan penelitian tentang "Penerapan Model Pembelajaran Kooperatif Tipe Think Pair Square (TPSq) Untuk Meningkatkan Hasil Belajar Siswa Kelas VII SMPN 4 Kota Bengkulu”.

Berdasarkan latar belakang masalah yang dipaparkan, maka rumusan masalah yang dibahas dalam penelitian ini adalah: Bagaimana menerapkan model pembelajaran kooperatif tipe Think Pair Square (TPSq) untuk meningkatkan hasil belajar siswa kelas VII SMPN 4 Kota Bengkulu pada pokok bahasan Aljabar?

Berdasarkan rumusan masalah tersebut, maka tujuan penelitian ini adalah untuk mengetahui penerapan model pembelajaran kooperatif tipe Think Pair Square (TPSq) untuk meningkatkan hasil belajar siswa kelas VII SMPN 4 Kota Bengkulu pada pokok bahasan Aljabar.

\section{Metode Penelitian}

Jenis penelitian yang dilakukan adalah Penelitian Tindakan Kelas (PTK). Menurut Arikunto (2015:143-144), terdapat empat tahapan yang perlu dilakukan dalam penelitian tindakan kelas, yaitu (1) perencanaan, (2) pelaksanaan, (3) pengamatan, dan (4) refleksi. Penelitian ini dilaksanakan di SMP Negeri 4 Kota Bengkulu pada semester ganjil tahun ajaran 2018/2019. Subjek yang akan diteliti adalah siswa kelas VII 3 SMP Negeri 4 Kota Bengkulu yang berjumlah 32 orang yang terdiri dari 16 orang laki-laki dan 16 orang perempuan. 
Instrumen yang digunakan dalam penelitian ini adalah tes hasil belajar. Tes hasil belajar diberikan di setiap akhir siklus dengan tujuan untuk memperoleh data tentang hasil belajar matematika siswa dengan menerapkan model pembelajaran kooperatif tipe Think Pair Square (TPSq). Soal tes dibuat berdasarkan kompetensi dasar dan indikator pembelajaran. Data tes hasil belajar dianalisis dengan menggunakan nilai ratarata siswa dan ketuntasan belajar klasikal.

Nilai LKS dan tes akhir siklus digunakan untuk menentukan nilai akhir siklus yang diperoleh dengan persamaan berikut:

$N_{A}=\frac{\frac{\left(F_{1}+F_{2}+F_{3}\right)}{3}+2 S}{3}$

Keterangan:

$N_{A} \quad=$ Nilai akhir

$F_{1} \quad=$ Nilai LKS 1

$F_{2} \quad=$ Nilai LKS 2

$F_{3} \quad=$ Nilai LKS 3

$S \quad=$ Nilai tes akhir siklus

(Sudijono, 2011: 437-438)

Kemudian nilai akhir siklus dianalisis dengan menggunakan rata-rata nilai siswa, dan ketuntasan belajar klasikal siswa.

a. Nilai Rata-rata

Nilai rata-rata kelas $(\bar{X})$ dihitung menggunakan persamaan:

Keterangan :

$$
\bar{X}=\frac{\sum X}{N}
$$

$\bar{X} \quad=$ Rata-rata nilai siswa

$\sum X=$ Jumlah nilai siswa

$N$ = Banyak siswa (Daryanto, 2011:191)

b. Ketuntasan Belajar (KB) klasikal dihitung menggunakan persamaan:

$$
K B=\frac{\text { Banyak siswa yang tuntas belajar }}{\text { Banyak siswa }}
$$

(Daryanto, 2011:192)

\section{Hasil dan Pembahasan}

Untuk mengetahui hasil belajar siswa pada pembelajaran matematika setelah menerapkan pembelajaran kooperatif tipe Think Pair Square (TPSq), maka disetiap akhir siklus dilakukan tes akhir. Berikut ini merupakan hasil tes akhir dari siklus I sampai dengan siklus III yang ditunjukkan pada tabel di bawah ini:

Tabel 1. Rekapitulasi Hasil Belajar Siswa Tiap Siklus

\begin{tabular}{c|l|c|c|c}
\hline \multirow{2}{*}{ No } & Hasil yang & \multicolumn{3}{|c}{ Siklus } \\
\cline { 3 - 5 } & diperoleh & I & II & III \\
\hline 1. & $\begin{array}{l}\text { Rata-rata Nilai } \\
\text { akhir }\end{array}$ & 74.35 & 79.91 & 81.14 \\
2. & $\begin{array}{l}\text { Jumlah siswa } \\
\text { yang } \\
\text { tuntas }\end{array}$ & 15 & 22 & 26 \\
$\begin{array}{l}\text { Persentase } \\
\text { ketuntasan } \\
\text { belajar klasikal }\end{array}$ & $76.67 \%$ & $83.33 \%$ & $93.33 \%$ \\
\hline
\end{tabular}

Berdasarkan Tabel 1 diatas menunjukkan adanya peningkatan nilai rata-rata hasil belajar siswa dan ketuntasan belajar klasikal siswa di setiap siklusnya. Pada siklus I, nilai rata-rata hasil belajar siswa yaitu 74.35 dengan persentase ketuntasan belajar klasikal yaitu $76.67 \%$. Banyaknya siswa yang tuntas pada siklus I adalah 15 dari 31 orang siswa. Pada siklus II, rata-rata nilai siswa meningkat menjadi 79.91 dengan banyaknya siswa yang tuntas yaitu 22 dari 31 orang siswa dan persentase ketuntasanbelajar klasikal yaitu $83.33 \%$. Pada siklus III nilai ratarata siswa terus meningkat menjadi 81.14 dengan persentase ketuntasan belajar klasikal siswa yaitu 93.33\% artinya sebanyak 26 dari 31 orang siswa tuntas pada siklus III.

Peningkatan hasil belajar matematika pada setiap siklus diakibatkan oleh kegiatan pengelompokkan siswa dengan cara pasangan telah memacu berpikir siswa dalam memahami konsep matematika maupun dalam menyelesaikan permasalahan. Selain itu dibantu juga dengan menggunakan alat peraga dan LKPD dalam proses pembelajarannya.

\section{Kesimpulan}

Berdasarkan hasil penelitian yang telah dilakukan di kelas VII 3 SMP Negeri 4 Kota Bengkulu, dapat disimpulkan

Penerapan model pembelajaran Think Pair Square (TPSq) dapat meningkatkan hasil belajar matematika siswa kelas VII 3 SMP Negeri 4 Kota Bengkulu dengan cara:

a. Menggunakan alat peraga dalam pembelajaran untuk membantu dan mempermudah siswa dalam memahami materi yang dipelajari.

b. Menyajikan LKPD sebagai penunjang media pembelajaran dan sebagai sarana yang digunakan untuk meningkatkan kompetensi siswa dalam kelompok

c. Memberikan arahan dan bimbingan kepada siswa yang masih mengalami kesulitan dalam pembelajaran dan meminta siswa untuk lebih sering belajar dan mempelajari materi yang akan dipelajari selanjutnya. 
d. Memberikan penghargaan terhadap siswa yang aktif dalam pembelajaran untuk memancing minat siswa dalam belajar.

e. Mengumumkan nilai tes akhir setiap siklus untuk membuat siswa lebih termotivasi lagi dalam belajar dan meningkatkan lagi hasil belajarnya.

Hasil belajar yang diperoleh siswa baik nilai rata-rata ataupun ketuntasan belajar klasikal setiap siklus mengalami peningkatan. Pada siklus I, nilai rata-rata hasil belajar siswa yaitu 74.35 dengan persentase ketuntasan belajar klasikal yaitu $76.67 \%$. Banyaknya siswa yang tuntas pada siklus I adalah 15 dari 31 orang siswa. Pada siklus II, rata-rata nilai siswa meningkat menjadi 79.91 dengan banyaknya siswa yang tuntas yaitu 22 dari 31 orang siswa dan persentase ketuntasanbelajar klasikal yaitu $83.33 \%$. Pada siklus III nilai ratarata siswa terus meningkat menjadi 81.14 dengan persentase ketuntasan belajar klasikal siswa yaitu $93.33 \%$ artinya sebanyak 26 dari 31 orang siswa tuntas pada siklus III.

\section{Daftar Pustaka}

Arikunto, S. dkk. 2008. Penelitian Tindakan Kelas. Jakarta: PT Bumi Aksara.

Daryanto. 2011. Penelitian Tindakan Kelas dan Penelitian Tindakan Sekolah. Yogyakarta: Gava Media.

Utami, Nita P. dkk. 2014. Kemampuan Penalaran Matematis Siswa Kelas XI IPA SMAN 2 Painan Melalui Penerapan Pembelajaran Think Pair Square. UNP, 3 (1): 7-12.

Sudijono, Anas. 2011. Pengantar Evaluasi Pendidikan. Jakarta : Rajawali Pers. 